\title{
THE QUR'AN IS THE FORGOTTEN BOOK (A STUDY OF THE QUR'AN TEACHING SYSTEM FAILURE IN PROVIDING QUR'ANIC UNDERSTANDING TO THE YOUNG PEOPLE)
}

\author{
Ermawati \\ Sulthan Thaha Saifuddin State Islamic University (UIN) Jambi \\ ummi3mm4@gmail.com
}

\begin{abstract}
This study highlights how the existence of the Qur'an as a guide for life for young people aged 25-40 years in the rural areas in Jambi Province. The study is based on the author's observation of the phenomenon that occurs in rural communities, where young people aged 25-40 years do not present in the five-time prayers in the mosque, the increase of criminals, rampant forest burning and rampant Wild gold mining in rural areas conducted by young people aged 25-40 years, where some of the phrase is closely related to their understanding of the Qur'an content. From here the question arises, Do they understand the content of the Qur'an and do they follow the guidance of the Qur'an in living their lives? This research is a non participant research by doing observation, questionnaire and interview to selected sample from young aged 25-40 in rural area in 8 of 9 district in Jambi Province.
\end{abstract}

Keywords: Qur'an teaching system, understanding of Qur'an

\section{Introduction}

Jambi Province is one of the provinces in Indonesia located on the island of Sumatra, formed on 25 June 1958 with the motto of Sepucuk Jambi sembilan lurah. Consisting of 9 districts and 2 municipalities. Total population of Jambi Province consists of 3. 412,000 people consisting of several ethnic, Malay, Javanese, Kerinci, Minang kabau, Banjar, Sundanese, Bugis and others. The majority or about $96.5 \%$ of Jambi's population are Muslims. In general the people of Jambi province are a peaceful Muslim society, holding tight to customary norms, ethics of polite and raising the value of brotherhood.

Based on residence area, Jambi province community can be categorized into 3 communities, Urban community, transmigration area and rural area. The people of urban areas are the people living in the provincial, municipality and district capitals. Transmigration is a community living in transmigration areas and is a community imported from Java, such as Bahar river communities, Rimbo Bujang, Singkut and others in Jambi province. Villagers are rural people living in rural areas where the majority occupy the interior area and the riverbank area of Batang hari river, they are mostly made up of indigenous Malay Jambi and Jambi kerinci. The majority of rural community members work as farmers, in addition to those who work as civil servants, traders and other entrepreneurs.

The past rural areas were the basis for the development of Islam in the provinces of Jambi. Mosques, surau and langgar always enlivened by the people of all ages to study religion. The mouque was a community centre and many types programs and social and educational activities were conducted under one roof. (Halim Tamuri and Friends, 20121 - 10). 
However, in the decade of 90's until today the phenomenon is fading. Qur'anic teaching meeting (Pengajian) only dominated by children and elderly. Five times Praying in the mosque only in the presence of elderly people and even in small amounts. Young people present at the mosque only on Friday prayers in congregation or on the celebration of Islamic religious holidays. There was a significant change in the lives of rural communities. Crime figures tend to increase, drug traffickers have come from the hamlet community, the rise of illegal gold mining in the river Batang Hari and the rampant burning of land and forest. From the police data, the majority of caught perpetrators are people aged 25-40 who live in rural areas (about crime scene) incidents.

Changes that occurred as a background of the author's study carried out, some of the above events is an indicator of the weakening of religious understanding of society. The society as an association has a single soul and social thinking, and the latter generation punishable for the action of earlier generation. If the earlier generation brakes the nature the later generation will get the impact.(Ayatullah Murtada Muttahari, Sociology of the Qoran, part 1,7). Becouse the Universe has been designed in the relationship of pairs. (S.Abul ala al maududi, 1997,7). As a Muslim society, the rural community must have the Qur'an to be guided. The Devine revelation as contained in the Al-Quran andSunnah Constitutes the foundation of social order in Islamic society.(Hayatullah Laluddin,2014, vol 6). If they understand the teachings of the Qur'an, they will certainly build a harmonious relationship between human beings and between humans and nature.

"One can identify in the Holy Quran numerous rules intended to protect nature and the environment. Approximately 750 verses of the Holy Quran refer to various aspects of nature, the relationship between man and nature, vegetal and animal organism and their environment."

(Muhammad Hashim,2016"."Environmental Education in The Holy Quran" Lucrarile Seminarului Geografic "Dimitrie Cantemir "NR. 42,).

Previous research on Jambi society has been done by Hadri Hasan and Fuad Rahman, published in Jurnal Kontekstualita IAIN STS Jambi, about improving the religious quality of Jambi people through understanding the Qur'an(Improving the religious Quality of Jambi Society Through effort on understanding Al-Qur'an), the results of the research mentioned that the level of understanding of the Qur'an of Jambi society has been good but not maximally due to lack of ability to translate the Qur'an, lack of motivation from family, and social environment to carry out Religious activities and increasing behavior in worship.

As for this research the author specially targeted the rural community of the ages 25-40, by trying to explore how the existence of the Qur'an in their midst. Do they understand the content of the Qur'an, what is the factor that causes them not understand the content of the Qur'an? And Do they still follow the teachings contained in the Qur'an?

\section{Methods}

The method used by this research is qualitative descriptive, data collection through survey, interview and questionnaire and observation note, data analysis using qualitative data analysis in the form of data reduction, data presentation and conclusion.

\section{Result and Discussion}

\section{Al-Qur'an Teaching System in the Rural Areas of Jambi Province}

The study and teaching system of the Qur'an in the rural area of Jambi province is carried out in several forms:

1. Qur'anic Teaching Meeting (Pengajian) between Maghrib and Iysa '(PAMI). 
Qur'anic Teaching Meeting (Pengajian) between Maghrib and Iysa '(PAMI) is a class or a meeting followed by children held in Langgar, Mosques or at teacher house. This recitation focuses on teaching the children to be able to recite the Qur'an by the method of sorongan and iqra '. Starting from studying Iqra / Juz amma until children are able to read the Qur'an. On one night in each week children are taught Fiqh Islam on how to purify, pray and other deeds.

2. A weekly or monthly wirid yasin Meeting.

This recitation is a recitation for adults, held every once a week or once a month. Weekly meetings are usually held on the afternoon of Friday or Sunday. In the assembly of this recitation held Yasin reading, qulhu tahlil together with the teaching of fiqh and arisan. Implementation is arranged in rotation from house to house according to the turn of the recipients of the arisan which has been cast in the previous meeting. In some villages, this recitation is held in mosques or langgar.

3. Afternoon recitation in Madrasah (learning Al-Qur'an and other Islamic sciences for elementary-level children).

This study was conducted in Madrasahs in the village. Almost every hamlet has a madrasah. The afternoon recitation in Madrasah focuses more on the introduction of other Islamic sciences than the Qur'an. Such as Fiqh, aqidah, Islamic history and learning to write in Arabic

4. Class of Quran recitations and tartil at the house of Al-Qur'an teacher (guru ngaji).

In some rural areas in Jambi province there are several Quran recitation and tartil training centers conducted at the house Guru Ngaji who teaches Qur'anic recitations and tartil.

\section{The Existence of the Qur'an for young people aged 25-40 years in the rural area of Jambi Province.}

In a series surveys conducted in rural areas in several districts within Jambi province, the authors found some surprising phenomena about the practice of Islam and Qur'anic recitation:

1. From the observation of the implementation of prayer 5 time in the mosque, the authors found some facts that is, first, there are some mosques that do not perform azan and prayers in congregational prayers zhuhur and Asyar. Secondly, in most hamlets, prayers in mosques at the time of prayer maghrib, Isya and early morning (subuh) only attended by middle-aged jama'ah and elderly (50 years and over), in small quantities.

2. From the observation of the study between Maghrib and Isha in the Mosque and in langgar:

- Qur'anic Teaching Meeting (Pengajian) between Maghrib and Iysa '(PAMI) at the mosque and in the langgar is attended by children aged 5 to 12 years, the authors did not find children aged 13 years and over and adults aged 25-40 years who attended the recitation, this fact raises a question where teenagers and The adult is reciting?

- In most mosques and langgar there is no translation of the Qur'an, and the availability of the Qur'an is very limited.

- Most of the mosques still hold weekly or monthly recitation by reading yasin together and presenting lecturers, especially on the celebration of Islamic holiday.

3. From the research instruments and interviews to the young people aged 25-40 years, the authors get the data : 
- Questions about the meaning of the Qur'an for them in life, $85 \%$ of respondents replied that the Qur'an is the holy book of Islam and is a guidance to the life of Muslims.

- The question of whether they read the Qur'an by understanding the meaning of the verse read, $80 \%$ replied that they did not understand the meaning of the verse that was read. Unfortunately they can't understand the content of the Qoran even though the Qoran has explains everything that needed in human life.(Sadik Kirazli, 2003,7)

- Questions about the ownership of the Qur'an, 78\% Respondent admits do not have the translation of the Qur'an.

- The question of some of the themes in daily life described by the Qur'an, 85\% can not explain these themes.

From the respondent's answer above looks a phenomenon of their lack of understanding of the existence of the Qur'an as a way of life (life guidance) and low understanding of the content of the Qur'an even further can be concluded that young people aged 25-40 years no longer using the Qur'an as a guide of life.

One contradictory fact here is that they recognize the Qur'an as a guideline for the lives of Muslims but they themselves do not understand, do not care and do not try to understand the content of the Qur'an. Yet clearly and plainly God has said that the Qur'an is a guide for man in life. As a guide the Qur'an guides man in all aspects of his life. Such guidance is contained in the content of Qur'anic verses as well as in concepts offered by the Qur'an. (Zamir Akhtar Khan,Establishment of Quranic System of Life ,The Dialogue). It provides guidance for all activities either these are individual, social, material and moral, legal and cultural, economic and political and national or international. Islam invites the man to enter the fold of Islam without any vacillation and to follow Allah guidance in all fields of life. (Khurshid Ahmad, 1999)

As the book of guidance in human life Al-Qur'an has some ideal functions as follows: (Manna' Khalil al-Qattan, Muzakir AS terj, 2000:20-22)

1. Al-qur'an as Nur (light) as the word of Allah in Surah al-Nisa 173

"O mankind! Verily there has come to you a convincing proof from your lord: for we have sent unto you a light (that is) manifest.

The light in this verse can be understood as the light of truth. The Qur'an is truth, dabbling in truth is truth, something that arises from truth is also truth, the end result of all that is truth itself. (Abd. Rahman Dahlan,1997: 22)

When Nur is interpreted as the light of truth attributed to social life, then the Qur'an can be interpreted as the basic concept of social change. The process of social change has two sides, the first side is the content of the Qur'an which is the focal point of the orientation of the process of social change contained in the form of laws and methods that we call shari'ah and the other is the objective reality that has been Institutionalized As the social institution of society in which the Prophet and his Companions lived. So the ideal society of qur'ani that ever existed in history is a society that lived during the time of the Prophet .(Al-allamah Muhammad Bagir Shadr, Pedoman Tafsir Modern,38)

2. The Qur'an serves as Huda (guidance), Syifa '(healer), Rahmat (affection) and mau'izah (willing) as the word of God in Surah Yunus verse 57:

" O mankind! There has come to you a direction from your lord and healling for the ( diseases) in your hearts - and for those who believe, a guidance and a mercy."

In its function as syifa ', the Qur'an is believed to bring peace of mind to its readers and listeners.

As The Word of Allah (Kalamullah), The Quran has the power to affect humans. 
His influence not just on the visible behavior from individual and communal, even influence will enter the halls of atoms and blood cells in the human body although only by listening alone. (Daris Tamin, 2016, pp. 1-8). A study of a number of Muslim and non-Muslim volunteers, who can speak Arabic and who can not speak Arabic, shows that recitation of Qur'anic verses against them brings a calming influence of up to $97 \%$, the effect seen in the form of physiological changes Decreased nervous tension. (M. Qurais Shihab, 1998: 236)

3. The Qur'an as Mubin / explanation as mentioned in al maidah 15-16:

"O people of the book! There has come to you Our messenger, revealing to you much that you used to hide in the book, and passing over much (that is now unnecessary) there has come to you for, Allah a (new) light an a perspicuous book- 16 Wherewith Allah Guides all who seek His good pleasure to ways of peace and safety, and leads them out of darkness, by Hiss will unto the light- Guides them to a path that is Straight"

4. Al-Qur'an as Mubarak/blessed, Qs. al an'am 92

"And this is the Book which we have sent down, bringing blessings, and confirming the revelations which came before it. That you may warn the mother of cities and all around her. Those who believe in the hereafter believe in this (Book), and they are constant in guarding their prayers".

5. Al-Qur'an as Busyra / good news, Qs. Al baqarah 97

"Say : Whoever is an enemy to Gabriel-for he brings down the (revealation) to your heart by Allah's will, a confirmation of what went before, and guidance and glad tidings for those who believe".

6. Al-Qur'an as Basyir wa nazir warning carrier and bearer of good news, Qs. fussilat 3-4 "A book where of the verses are explained in detail a Qur'an in Arabic, for people who understand.- 4 Giving good news and admonition yet most of them turn away and so they hear not".

\section{Some causes of young people aged 25-40 no longer take the Qur'an as a guidance of life, among others:}

a. Lack of understanding that the Qur'an is a living guide.

For most of the young people of Jambi Province, reading the Qur'an is understood as a service that brings rewards, but the readings are only limited to read Arabic texts only. The reading of the Qur'an is not followed up by the effort of understanding alQur'an, so the understanding of the content of the verses that are read is not obtained. This fact is an irony that is not in line with the purpose of the descent of the Qur'an. The Qur'an is revealed to be a living guide; guidelines on how to live all aspects of life according to God's guidance, to seek sustenance according to God's guidance, to spend the treasure according to God's instructions and so on. The parable for the one who reads the Qur'an but does not understand its meaning the same as a person to seek a doctor, get a prescription, read and memorize it but not take the medicine. This phenomenon also happened in an other country like Malaysia. (Mohd Aderi Che Noh, et.al., 1338-1344).

b. The absence of a habit to understand the content of Al-Qur'an is caused by the Qur'an teaching system in society which does not emphasize them to understand the Qur'an. Some pacts on the matter are shown on:

- The Qur'an teaching system or recitation for the children in the recitation between Maghrib and Isha and also on the Qur'an Study in afternoon Madrasah only emphasizes the ability to read Al-Qur'an and understanding of tajwid only. It is the obligation of every Muslim to recite the holy Quran with authentic sound 
production and tajweed . (Nur Hannah Saari1,et.al 2012 :85-92). Yet to be able to live the meaning of the content of Al-Qur'an then humans must learn Arabic and learn some other science of the Qur'an and do tadabbur against Al-Qur'an. Muslims are always reminded of the advantages of reading and completing the Quran but are rarely emphasized on the advantages of tadabbur al-Quran. (Ishak Abdul Manaf, et.al, 2017:100-114). As Allah says In Sura Muhammad verse 24:

"Do not they earn to see the Qoran, or are their hearts locked up by them".

- The pattern of teaching the Qur'an is more emphasis on reading skills in terms of recitations (tilawah and tartil), without focusing on teaching the meaning of the verses of the Qur'an.

- The recitation of the Qur'an in the recitation of wirid yasin is only carried out by reading yasin, qulhu tahlil together without the follow-up with studing interpretation of the Qur'an that is guided by the teacher. So the authors found many people or members of the Wirid Yasin memorized a sura yasin but did not understand the contents of the sura.

c. Limitations of containers or assemblies and interpretation teachers of the Qur'an in rural communities.

d. Young people aged 25-40 years have partially stopped reciting when they were teenagers. The study in surau, langgar, madrasah of hamlet or in mosque is only average followed by children aged 4 years up to age 12 years. As for teenagers aged 13 years and over are no longer willing to follow pengajian because they already feel able to read Al-Qur'an and embarrassed to follow pengajian, the average teenager only to review until the age of 12 years. So if there are teenagers aged 14 years and over still studying in langgar or surau will look strange and have no peers in the pengajian.

e. The limited time to sit studying the Qur'an is also one of the dominant reasons that respondents have expressed. Most of their time is spent doing worldly work (work, family gathering, play and community).

From the development of research instruments and interview results the authors found that the limited time for these young people not only in terms of reading and understanding the Qur'an but also the limited time in five times praying and fasting Ramadan. $45 \%$ claimed to perform their own prayers, and followed the Friday prayers every week. $40 \%$ claimed to pray five times but perforated. $15 \%$ claimed to perform maghrib prayers only.

"we can't perform five time prayers becouse we leave for work / garden/ forest on early morning, we came back home after sunset, in a full exhaustion. Tomorrow work again, that's the routine to earn a living and send our children to school"

$35 \%$ claimed to perform Ramadan fasting. $60 \%$ said they did not perform fasting in Ramadan because of the heavy work to be done in earning a living.

"We are heavy workers, if we do fast in Ramadhan we can't do our duty.". (Interview with oil palm plantation workers in Tanjung Aur village, Tebo district, Jambi)

f. Lack of utilization of gadgets to study the Qur'an. In terms of gadget utilization, there is an inverse comparison between the recognition of the limited time to read the Qur'an with their involvement with gadgets and social media. When asked about the use of free time after returning from work $45 \%$ admitted to spending time with mobile phones (telphon call, messaging and social media). 78\% said they spent chatting with their neighbors and other social activities.

Actually they have to actively use their gadget to study the Qoran becouse there are so many websites providing the methode of learning the Qoran. As Mohammed, S.A.E, et.al 
said that Great efforts in recent years were conducted to adapt information technology and computer applications, perticularly the use of websites and web pages in religious sciences and provided to all categories of Muslims worldwide in all forms, whether printed, audio or video to benefit all classes of Muslim society. (Mohammed, S.A.E., et.al. 2014,7,150-161). 'In general the increase in online resources for the study ofthe Qur' iin is notable.(Abdolkarim Soroush,2011:7)

\section{Conclusion}

In an effort to improve people's understanding of the content of the Qur'an, it is necessary to reform the system of teaching and recitation of the Qur'an in the Society. Not only concentrated on teaching Iqra and Juz'amma activities but should be divided into several groups. The childhood age group learns to read the Qur'an, the Youth Group learns the meaning and sciences of the Qur'an. The adult group studies the tafsir and the themes of life that exist in the Qur'an.

With this kind of grouping, it is hoped that no teenagers will stop studing the Qur'an because they are embarrassed. When his ability has not been too fluent in reading the Qur'an he can join a youth group where he can keep reading the Qur'an and studying other Qur'anic sciences. Grouping for adult age is also very important to do in order to generate public spirit to study the Qur'an thoroughly and profoundly.

Besides, it is also necessary to get attention from Local Government in the form of procurement policy of Al-Qur'an translation for Mosques and Mushalla scattered in rural areas in Jambi Province.

\section{References}

Anonim, 2010, Mushaf Al-Kalam, Al-Qur'an Terjemahan dwi bahasa Bahasa Indonesia-Inggris, Bandung: Al-Mizan Publishing House. Cet. I

Che Noh, Mohd Aderi, et.al., 2013, "The Study of Quranic Teaching and Learning : A Review in Malaysia and United Kingdom", Middle-East Journal of Scientific Research 15 (10): 1338-1344,2013 IDOSIPublications, DOI : 10.5829/idosi.mejsr.2013.15.1

Dahlan, Abd. Rahman. 1997, Kaidah-kaidah penafsiran Al-Qur'an, Bandung: Penerbit Mizan

Hashim,Muhammad,2016,"Environmental Education in The Holy Quran" Lucrarile Seminarului Geografic "Dimitrie Cantemir "NR. 42,".

Khan, Zamir Akhtar,Establishment of Quranic System of Life, The Dialogue Volume III, Number 1

Kirazli, Sadik,2003, Changes in Islamic Hermeneutics and Social Revolutions : a Comparative study of Turkey and Algeria, US ProQuest Information and LearningCompany.

Khurshid, Ahmad, (1999) "Islamic Perception of Business Ethics and the Impact of Secular Thoughts on Islamic Business Ethics International" Journal of Academic Research in Business and Social Sciences March 2012, Vol. 2, No. 3

Laluddin, Hayatullah, 2014, Conception of Society and Its Characteristic From an Islamic Perspektive, International Journal of Islamic Thought, Vol 6 December www.ukm.my/ijit

Manaf, Ishak Abdul et.al, 2017, "The Concept of Tadabbur and the Impacts of the 5 Minutes Program with Al-Quran: A Case Study among Student Teachers in IPG KSAH” Tinta Artikulasi Membina Ummah 3(1), Malaysia

Maududi, Abul A'la, 1997, Social System of Islam, Lahore : Islamic Publication limited

Muttahari, Ayatullah Murtada, Sociology of The Qoran Part 1, IslamicMobility.com 
al-Qattan, Manna' Khalil. Drs. Muzakir AS terj, 2000, Study ilmu-ilmu Al-Qur'an, Jakarta : Litera Antar Nusa. Cet v.

Saari, Nur Hannah,et.al ,2012, "Factors Affecting the Learning of the Holy Quran among Severely and Profoundly Hearing-Impaired Children with a Cochlear Implant",IOSR Journal of Humanities and Social Science (JHSS). Volume 2, Issue 1

S.A.E, Mohammed., et.al. "Educational system for holy Quran and Its Sciences for Blind and Handicapped people Based on Google speech API", Journal of Sotfware Engineering and Applications, 2014,7,150-161, Published Online March 2014 on SriRes

Shadr, Al-allamah Muhammad Bagir. Hidayaturrakhman, terj, 1992, Pedoman Tafsir Modern, Jakarta: Risalah Masa

Shihab, M. Quraish. 1998, Mukjizat Al-Qur'an. Jakarta : Penerbit Mizan. Cet III

Soroush, Abdolkarim, 2011, New Perspectives on the Qur'an;The Qur,an in its historical context 2, Edited by Gabriel Said Reynolds " Taylor\&FranclsGroup London and New York : 11 Routledge.

Tamin, Daris,2016, "Applying Qur'anic contemplation in counseling" COUNS-EDU The International Journal of Counseling and EducationVol.1, No.1,

Tamuri, Halim and Friends, 2012,"A New Aproach in Islamic Education : Mosque based teaching and learning", Journal of Islamic and arabic education 4 (1) 